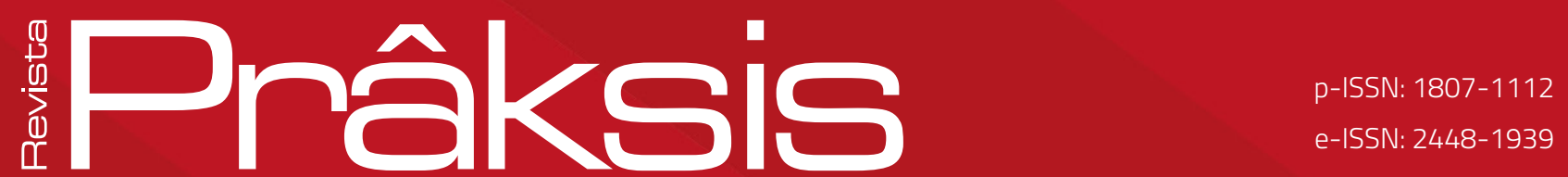

Recebido em: 21 de março de 2019

Aprovado em:15 de julho de 2019

Sistema de Avaliação: Double Blind Review

RPR |a. $16 \mid$ |n. 3 | p. 05-24 | set./dez. 2019

DOI: https://doi.org/10.25112/rpr.v3i0.1976

\title{
PEDAGOGY IN FINNISH HIGHER EDUCATION: A CASE EXAMPLE OF HÄME UNIVERSITY OF APPLIED SCIENCES
}

\section{PEDAGOGIA NO ENSINO SUPERIOR FINLANDÊS -} CASO EXEMPLO DA UNIVERSIDADE DE CIÊNCIAS APLICADAS HÄME

\section{Carolina Carvalho}

PhD from State University of Campinas, Brazil. Adjuncto professor at Federal University of ABC - UFABC.

E-mail: carolina.carvalho@ufabc.edu.br

\section{Mervi Friman}

PhD from the University of Jyväskylä, Finland. Research Manager in Häme UAS/Innovative Expertice.

E-mail: mervi.friman@hamk.fi

\section{Seija Mahlamäki-Kultanen}

PhD from the University of Tampere, Finland. Dean in HAMK School of Professional Teacher Education.

E-mail: seija.mahlamaki-kultanen@hamk.fi 


\section{ABSTRACT}

In the context of pedagogical development in higher education (HE) this research is a case study concerning Häme University of Applied Sciences (HAMK), in Finland. The focus of the study is to make visible the correspondence between the international and national higher education policy emphasis and an individual higher education institution. Ten thematic approaches in higher education pedagogy were identified in a content analysis of policy documents, and from earlier interviews in Finnish higher education institutes. The data for this study was gathered in subsequent interviews at HAMK and was compared with these ten thematic approaches. The results show how the national and institutional pedagogical emphasis correspond in the case of universities of applied sciences (UAS). The correspondence with the ten pedagogical emphases were classified as (1) strongly consolidated, (2) currently highlighted and (3) less emphasized. The conclusion is that it is challenging and complicated to apply pedagogical goals systematically considering the various attributes from a world in constant change. In-house prioritize needs awareness of strategy, negotiations, and co-operation. The main points for the successful pedagogical development are (1) prioritization of the emphasis, (2) systematic progress and quality assurance and (3) co-operation within the pedagogic actors.

Keywords: higher education. University of applied sciences. Pedagogy. Pedagogical strategy.

\section{RESUMO}

No contexto do desenvolvimento pedagógico no ensino superior (ES), esta pesquisa é um estudo de caso sobre a Universidade de Ciências Aplicadas Häme (HAMK), na Finlândia. O foco do estudo é tornar visível a correspondência entre a ênfase da política de ensino superior internacional e nacional e uma instituição de ensino superior individual. Dez abordagens temáticas na pedagogia do ensino superior foram identificadas na análise de conteúdo de documentos políticos e entrevistas em institutos de ensino superior finlandeses. Os dados coletados em entrevistas à HAMK foram comparados com essas dez abordagens temáticas. Os resultados mostram como a ênfase pedagógica nacional e institucional corresponde no caso da Universidade de Ciências Aplicadas (UAS). A correspondência das diferentes ênfases pedagógicas é classificada como (1) fortemente consolidada, (2) atualmente destacada e (3) menos enfatizada. A conclusão é que é desafiador e complicado estabelecer metas pedagógicas de maneira sistemática, considerando os vários atributos de um mundo em constante mudança. As prioridades internar necessitam da concientização da estratégia, negociações e cooperação. Os pontos principais para o sucesso do desenvolvimento pedagógico são (1) a priorização da ênfase, (2) o progresso sistemático e a garantia de qualidade e (3) a cooperação entre os atores pedagógicos.

Palavras-chave: Ensino Superior. Universidade de Ciências Aplicadas. Pedagogia. Estratégia Pedagógica. 


\section{INTRODUCTION}

In the last decades, the global world undergoing constant changes has challenged higher education institutes (HEI) to create, to innovate and to build new ways of teaching and learning so that students can learn and develop competences required for the 21st century. Several works have discussed the importance of continuous pedagogical development in HEls, as well as the need for re-thinking and renewing practices to support students' development and prepare them to face the near future (EGGINS, 2003; SPORN, 2003; TAYLOR, 2003; VIEIRA, SILVA \& ALMEIDA, 2009; BIGGS \& TANG, 2011; KETTUNEN, 2011; BARNETT, 2013; RYAN \& TILBURY, 2013; JONGBLOED \& VOSSENSTEIN, 2016; OSMAN \& HORNSKY, 2017; PIRES et al., 2018; KUNNARI, 2018A).

In Finland, HEls are providing new learning practices and several signs of progress in the field have been noticed. For instance, HEls are defining strategies, including their pedagogical emphasis, according to their own interests and aligned to the Ministry of Education and Culture (MoEC) agreement, settled individually with each of the HEIs (NURMI \& MAHLAMÄKI-KULTANEN, 2015). Other examples in the Finnish context include the teachers' role as a facilitator instead of a transmitter of information. Also, the HEls have a renewed curricula focus on competences in close connection with companies, in order to promote learning towards working life, besides other advancements (POSTAREFF et al., 2007; PARPALA \& LINDBLOM-YLÄNNE, 2007; KETTUNEN, 2011; KUNNARI, 2018; CARVALHO et al., 2018; FRIMAN et al., 2018; KUNNARI et al., 2018). There is a substantial challenge in prioritizing and resourcing the various demands.

In this context, one Finnish HEl that has been playing an important role in pedagogical development is HAMK. HAMK has established pedagogical targets, provided support for teachers and students, engaged in projects and has developed the ability to face this challenge with other HEls. The aim of this research was to analyze how HAMK's pedagogical emphasis corresponds with the national targets on the policy level. In order to understand this, the authors interviewed one of HAMK's managers, HAMK's staff connected to important projects and HAMK's experts in the pedagogical field. A semi-structured interview was conducted based on ten thematic key points which came from an earlier study (CARVALHO et al., 2018) in which the authors used two different data sources which they analyzed. First, the policy documents from the European Union (EU), the Finnish Ministry of Education (MoEC) and the Finnish Education Evaluation Centre (FINEEC). Second, from interviews with pedagogic experts from all Finnish universities (14) and UASs (25). The aim of the current study was to analyze the current situation in one UAS, HAMK, and determine what kind of pedagogical emphasis dominates the institute and how HAMK reflects the national key areas. 


\section{THE UNIVERSITY OF APPLIED SCIENCES CONTEXT}

The establishment of the UASs in Finland and the influence of the European Union (EU) are important to understand the Finnish UASs and their pedagogy. UASs were established at the beginning of 1990s in Finland. The basic idea was to construct a so-called dual model in the Finnish higher education sector, in which 14 traditional universities already operated. In a merging process earlier colleges were put together mostly regionally. In two cases, the bases for integration were content based (deaconess education and humanitarian education). The MoEC and correspondingly the UASs profiled themselves as work-related, regional institutions, representing the integration of theory and practice. In the 1990s the ideas of so-called mode 2 knowledge production, in which multidisciplinary teams are brought together for short periods to solve specific problems (GIBBONS, 1994) gained significant interest and was applied in the ideas and practices in UASs. The regional emphasis was due to the fact that their institutional history often involved local or regional ownership or national regional policy which pushed HEls to cover the whole country (SALMINEN, 2001). The fundamental difference between traditional universities was the more practical than research-based orientation. The character of the research activities in UASs is applied, which means close relations with customers in companies and users in society. Typically UASs are multidisciplinary. Degree programs in technology, health care and business are run in almost every UAS in . Beside this, degree programs in culture, the bioeconomy and human sciences exist in some UASs.

According to MoEC (2018) and Act 932/2015, the role of the UAS are to offer bachelor's and master's studies, to provide lifelong learning that responds to the needs of working life, to carry out applied research, to develop innovation activities that serve education at other UAS and to support regional development. This role shows how practice-oriented the UAS's strategy should be and, consequently, their approach to pedagogy. Also, aligned to the Act 932/2015, Kettunen (2011) affirm that the UAS is part of a wider community in their socio-cultural setting showing that their start point of the pedagogical development arises from the cultural theory and the constructivist view of learning (VYGOTSKY,1978; PIAGET, 2001). Other processes that had an important influence on the UAS's pedagogy approach was the Bologna declaration in 1999. To become part of the EU higher education area (EHEA) the Finnish UASs had to adapt some points. From 2004 to 2006 Finland has participated in a project called "Participation of Finnish Universities of Applied Sciences in the European Higher Education Area" which aimed to support the Finnish UAS in a transition to student-centered learning and competence-based curricula (RAMAN, 2007; PIRES et al., 2018).

Since the foundation of UASs, networking and collaboration on a national level has been a characteristic means of development. For instance student dropouts and counseling, RDI facilitation 
and internationalization have all been themes of national projects which have lasted from five years to becoming permanent networks. During the last government (2015-2019) about ten national networks were established to improve the quality of higher education. The themes of the networks have ranged from digitalization, to student counselling, career guidance, and pedagogy. In addition the Finnish HEls have their own strategies and development programs. So, coping in the middle of these pressures, is a challenge of HE management and as well the actors involved.

According to Finnish legislation (2001), all teaching staff needed to have a pedagogical qualification up to 2015, and since then most of the universities of applied sciences have demanded it still, although have been given more freedom to decide on their recruitment requirements. According to the legislation, the teaching staff need to have at least three years of work experience. Many of the staff members in universities of applied sciences have an integrated working plan with both teaching, development, innovation and research activities.

\section{METHODOLOGY}

This research is a single case study, based on the work by Yin (2014), in which HAMK represents a typical example of Finnish UAS (www.hamk.fi). It is multidisciplinary, regional and operates in six campuses in the Häme region. It is also the only HEl in the area. HAMK operates one of the five teacher education colleges in Finland.

The topic of the study is HAMK's pedagogical development, and the data for the study was gathered in semi-structured interviews with one vice rector from HAMK, two heads from the HAMK100 team (a program running at HAMK to improve teacher competence), one head from the LeaD Team (a project responsible for developing educational technology at HAMK) and eight of HAMK's experts. The interviews were conducted from June 2018 to June 2019 on HAMK's Visamäki campus situated in Hämeenlinna, in Finland. The interviews were conducted face-to-face and were recorded. The lengths of the interviews were from one to two hours. The authors have used a qualitative theory-based content analysis to understand the answers and to reflect on HAMK's pedagogical development (PATTON, 2002).

The basis for the interview was a study conducted by Carvalho et al. (2018) that identified ten pedagogical emphases in Finnish HE. These ten emphases were identified based on a document analysis with source documents from the EU, the MoEC and FINEEC and verified in practice with interviews conducted in 39 Finnish HEls (https://blogi.oamk.fi/2017/11/30/2903/). According to study, ten emphases are highlighted in Finnish $\mathrm{HEl}$. They are: a student-centered approach; digitalization; a working life orientation; a competence-based curriculum; the learning environment; internationalization; 
sustainable development; entrepreneurship; student counseling and guidance; and teaching competence and methods. These themes were elaborated on in a questionnaire composed of 38 questions aligned to these ten key points to evaluate HAMK's pedagogy, Figure 1.

Figure 1 - Ten Thematic Interviews Points

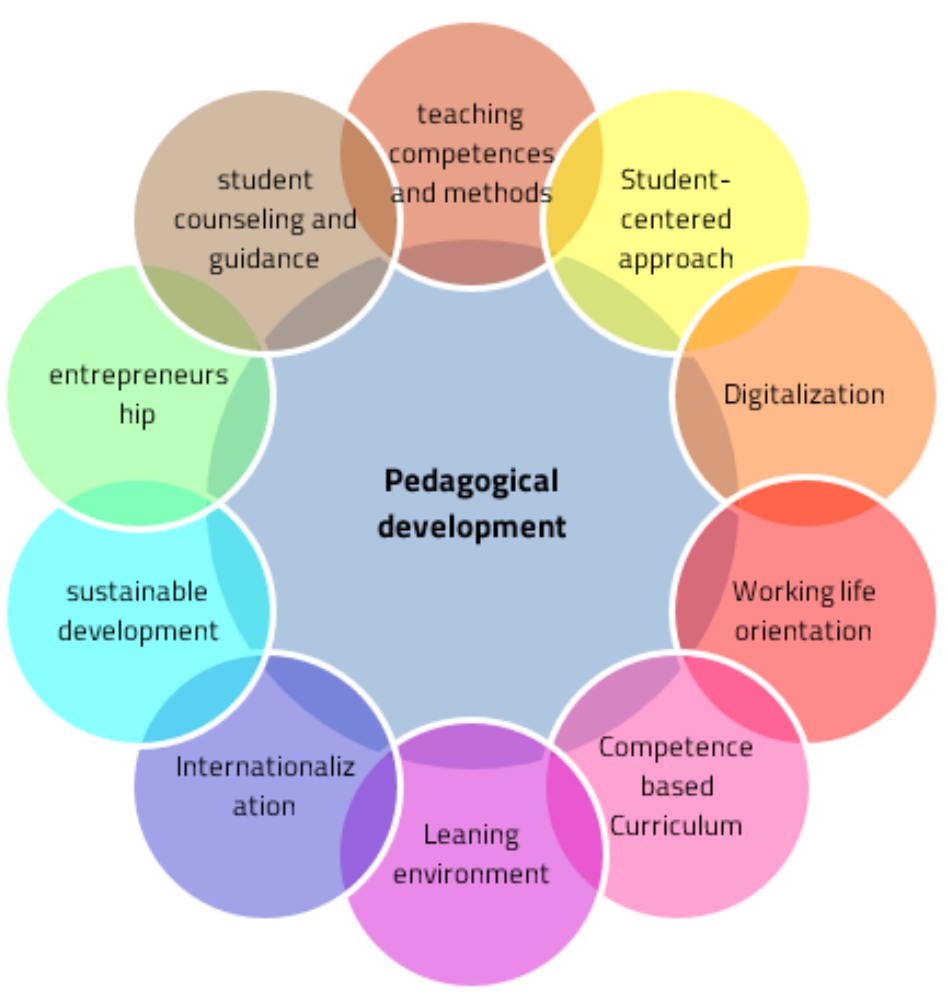

The interview themes were formulated in three sections as follows: The first section was constructed using general questions to understand how HAMK has developed its pedagogy and where the ideas behind the pedagogical development came from? The second section was based on the ten thematic key points. The questions were formulated (PATTON, 2002) in order to understand how HAMK has worked with each of the thematic points, in addition to how the university has given teachers and students support so that they can develop the competences necessary to face this new pedagogical challenge, and whether there were any projects running regarding the thematic points. The third section was designed to understand, what the main challenges in pedagogical development are.

The interviews were recorded and transcribed. After the transcription, the document was sent to the interviewees so that they could validate it and also add any missing information. After that, the final 
document was read, and each theme was analyzed separately. To complete the analysis the interviewees suggested links, materials and documents with the aim to enrich their answers. All the data was analyzed according to the themes and the results were compared to the agreement settled between HAMK and the MoEC. Other documents were also compared such as the HAMK100 program document, HAMK's Strategy 2030, as well as some articles and research by HAMK in order to complete the analysis and avoid overly personal perspectives.

Figure 2 presents this research process which was developed to evaluate HAMK's pedagogical development.

Figure 2 - Research Process

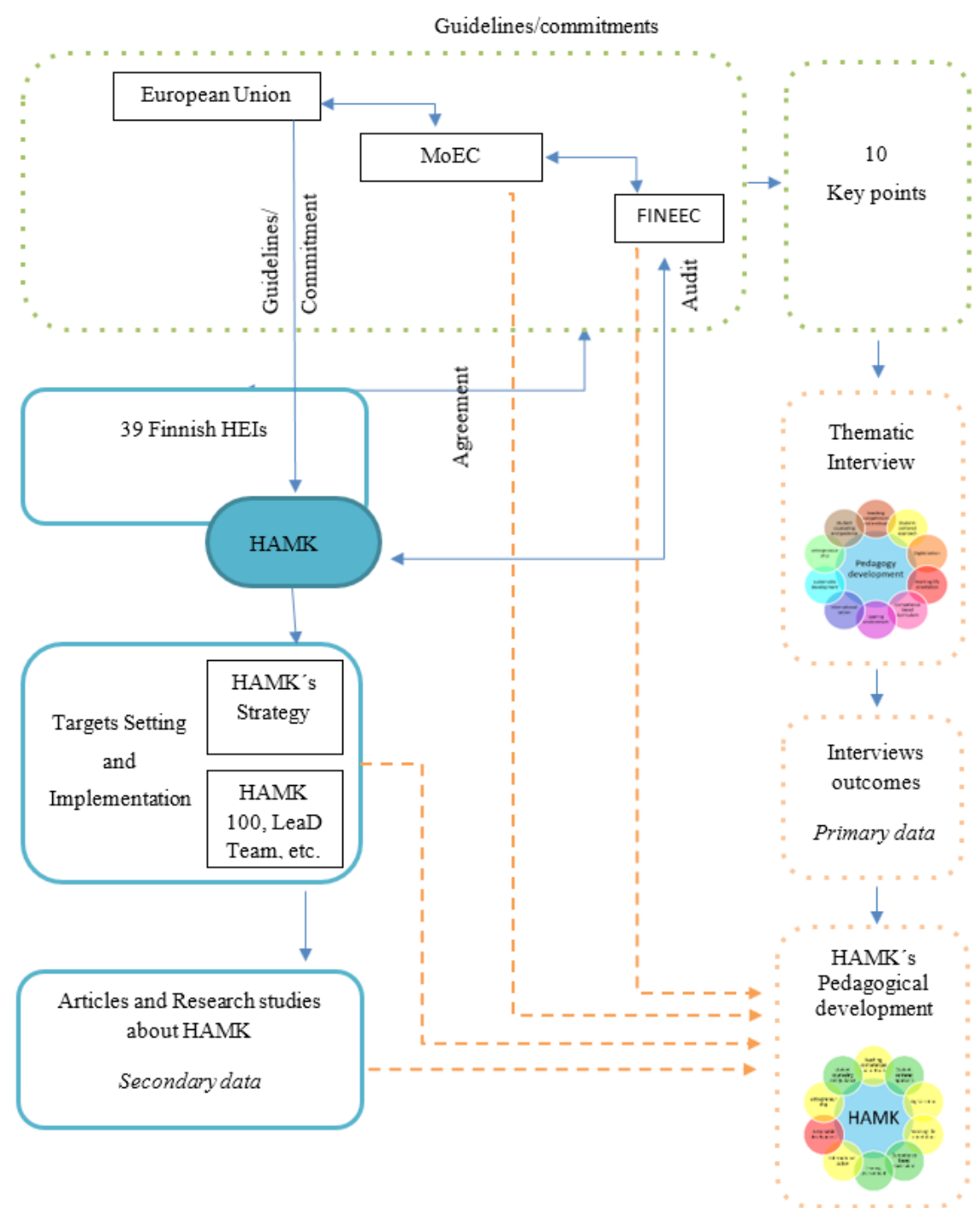




\section{RESULTS}

This chapter presents the results from the interviews and also the analyses carried out by the authors using a theory-based content approach (PATTON, 2002). The views here reflect the interviewees experiences related to information from the articles, research studies and HAMK's documents suggested by the interviewees.

Related to the first section of the questions, HAMK as a UAS has the same characteristics and starting point as every UAS in Finland and, consequently, the same background to its pedagogical development. To develop its pedagogy, HAMK follows strategies from the European Union and has made agreements with the MoEC to agree on goals and to plan their own strategy, as other UASs have in Finland. At the EU level, the document "Standards and Guidelines for Quality Assurance in the European Higher Education Area" is an example of an EU initiative to support HAMK. At the MoEC level, HAMK has followed reforms and guidelines, but in particular, HAMK has made an agreement that guides the institution into more deeply and specific developments, for instance, HAMK has agreed to enhance digitalization, internationalization, and provide entrepreneurial competencies (AGREEMENT BETWEEN THE MINISTRY OF EDUCATION AND CULTURE AND HÄME UNIVERSITY OF APPLIED SCIENCES FOR 2017-2020). In addition, HAMK has its own strategy. The ideas came from the MoEC but also in a participatory process including rectors, deans, principals, teachers, researchers and student feedback. The equal atmosphere and quality system at HAMK supports the staff to contribute positively to the system (FRIMAN et. al., 2014; CAMPBELL et al., 2016). In HAMK's strategy, the pedagogical approach highly emphasized includes guidance and counselling, digitalization, entrepreneurship, and internationalization (HAMK, 2018). The recommendation of the last audit (2016) was to encourage and support the staff to promote pedagogical innovations, and it has been put into practice (CAMPBELL, et al., 2016).

Besides this, HAMK has developed many coaching programs to develop teachers' competencies and support them to develop their teaching skills and methods, for example promoting a coaching program developed from 2010 to 2012 (KUNNARI; ILOMÄKI \& TOOM, 2018)and a HAMK 100 program (HAMK $100,2018)$. The LeaD Team Project is also an important means to support and develop teachers' digitals skills. HAMK has applied its own research, such as: the EEP (Empowering Eportfolio Process), KOPE (higher education pedagogy), eAMK (online UASs) (KUNNARI; ILOMÄKI \& TOOM, 2018; KUNNARI, 2018b; and KUNNARI, 2018c; KOPE, 2018 and eAMK, 2018) and partnerships to develop pedagogy, for instance with Aalto University in 2018 (http://www.hamk.fi/english/applicants/news/Pages/HAMK-and-AaltoUniversity-to-engage-in-strategic-cooperation.aspx). 
Therefore, nowadays six main aspects have influenced HAMK's pedagogical aims. We organized these into two groups; outside and in-house aspects: EU guidelines, the MoEC agreement, and societal needs show what HAMK takes into account when focusing on its goals. Coaching programs, research projects, and cooperation with partners - shows what HAMK has done to build a learning community and enhance its pedagogical development (Figure 3). Many attributes are taken into account in building the strategy and this makes the process even more complex and challenging for the rectors, principals and heads who should provide clear guidelines and ensure that the staff know the strategy, to engage then in the process.

Figure 3: The frame of HAMK's pedagogical activities.

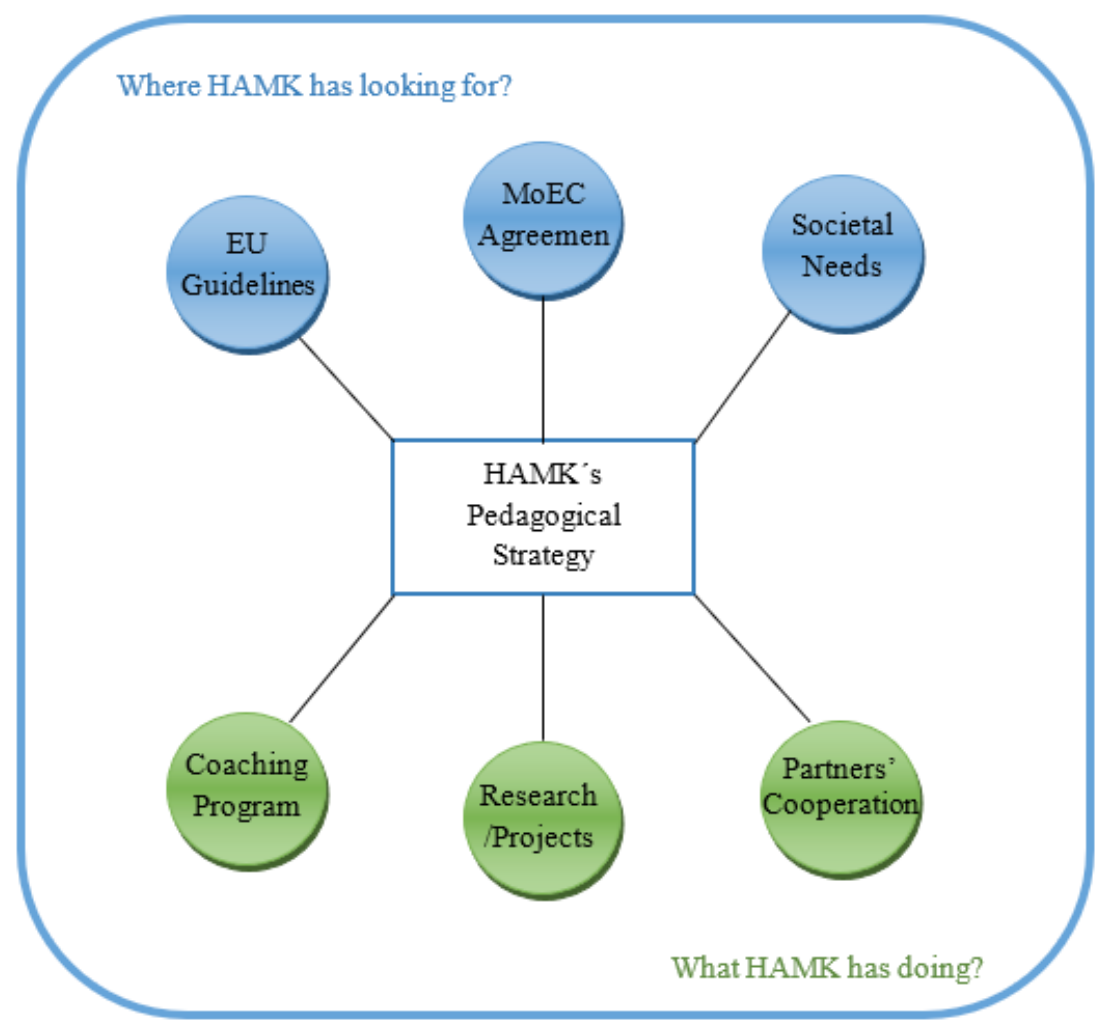

Although building and managing strategies is a challenging process, HAMK's culture and quality system (CAMPBELL et al., 2016, MALINEN et al., 2011) has motivated and built a positive atmosphere emphasizing a sense of belonging, autonomy and equal rights that, even though there are hierarchies, has allowed the community (teachers, staff, students, etc.) to contribute to the process (Figure 4). One concrete example of this is the HAMK strategy 2030. This was a process that lasted one year in which 
the managers invited three levels of players to become part of a team responsible for setting new targets and milestones so that HAMK could develop itself and look to the future and society's needs. These players were students, HAMK's staff and teachers. The actors engaged in a very open dialogue with different points of views and also varying needs. The final result was a map with targets and milestones for 2030. Now they are inviting units to look at the map and encourage them to take responsibility for the related areas.

Additionally, the quality assurance system is an important tool that supports the development of HAMK's staff and consequently HAMK. HAMK has a competence management system which combines teachers' personal goals and HAMK's strategic goals. Every year managers go through performance appraisal processes and in those meetings, one of the main discussion areas/themes is competence development. After this performance appraisal process, every teacher should have their own development plan. Part of this plan includes projects and research plans to participate in. When the development plans have been written, it is much easier to choose the right parts from the HAMK100 program, Lead Team, HAMK's strategy and other development actions.

Figure 4 - Cycle of learning in the community towards pedagogical development.

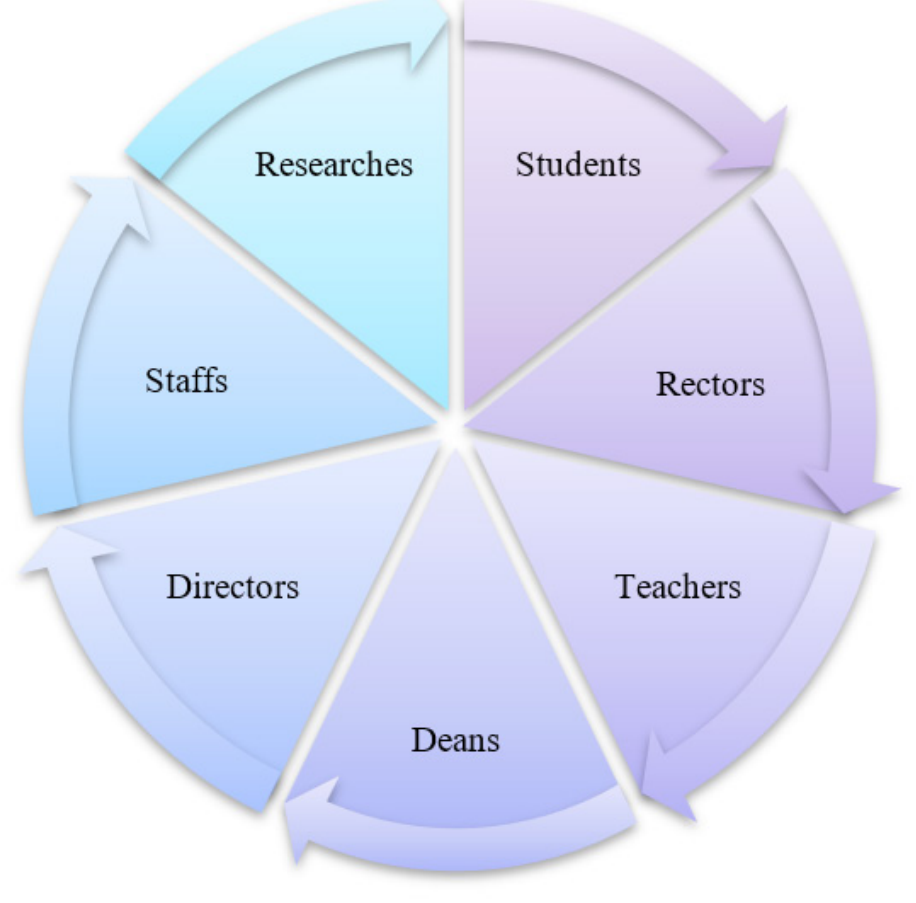


We authors discussed each of the ten key points in the second section of the questionnaire, complementing them with secondary data and HAMK's strategy documents. What these ten key points mean in practice at HAMK is summarized in Table 1.

Table 1 - Ten Pedagogical Approaches at HAMK

\begin{tabular}{|l|l|l|}
\hline \multicolumn{1}{|c|}{ Approaches } & \multicolumn{1}{|c|}{ Realizations and practical experiences } & \multicolumn{1}{c|}{ Sample Projects/Program/Activities } \\
\hline \multirow{5}{*}{$\begin{array}{l}\text { Student-centered } \\
\text { approach }\end{array}$} & $\begin{array}{l}\text { Teachers using pedagogical knowledge and tools } \\
\text { to put the student at the center of the learning } \\
\text { process. } \\
\text { Offering facilities, buildings and laboratories to } \\
\text { encourage students to build their own learning. } \\
\text { Flexible curriculum fits the students' interests and } \\
\text { allows them to be an entrepreneur on their own } \\
\text { path. } \\
\text { Encouragement of students to use and build } \\
\text { networks, which will support their studies. } \\
\text { Allow students to develop HAMK, consider their } \\
\text { feedback, having a council of representatives etc. }\end{array}$ & $\begin{array}{l}\text { Quality system includes systematic } \\
\text { practices to collect student } \\
\text { feedback and to utilize it effectively } \\
\text { (CAMPBELL et al., 2016). }\end{array}$ \\
\hline Digitalization & $\begin{array}{l}\text { HAMK100 project to support teacher } \\
\text { development. } \\
\text { Teachers' virtual campus, HAMK open badge and } \\
\text { ePortfolio. } \\
\text { Join important project to develop their knowledge } \\
\text { about digitalization. }\end{array}$ & $\begin{array}{l}\text { HAMK 100 program : https:// } \\
\text { blog.hamk.fi/hamk100/ KOPE } \\
\text { Wroject, EEP project :https://eepeu. } \\
\text { wordpress.com/ and eAMK project: } \\
\text { http://www.eamk.fi/en/frontpage/ } \\
\text { LeaD Team Project. }\end{array}$ \\
\hline orientation & $\begin{array}{l}\text { Enhancing cooperation with companies and } \\
\text { enterprises. } \\
\text { Participating in important national projects such as } \\
\text { TOTEEMl, motivating teachers to establish contact } \\
\text { with enterprises. }\end{array}$ & $\begin{array}{l}\text { National project: TOTEEMI (http:// } \\
\text { www.amktoteemi.fi/en). }\end{array}$ \\
\hline
\end{tabular}




\begin{tabular}{|c|c|c|}
\hline Approaches & Realizations and practical experiences & Sample Projects/Program/Activities \\
\hline $\begin{array}{l}\text { Competence-based } \\
\text { curriculum }\end{array}$ & $\begin{array}{l}\text { Curriculum development into competence-based } \\
\text { model using modules and teamwork since } 2014 . \\
\text { Participation in national projects related to it. } \\
\text { Support students to face this different approach } \\
\text { and offer guidance. }\end{array}$ & $\begin{array}{l}\text { “Developing a Competency- } \\
\text { Based Curriculum for Finnish } \\
\text { Higher Education" (http:// } \\
\text { ospe.utu.fi/tiedotteet/Ospe_- } \\
\text { kriteeristo_102×21cm_8s_2014_ } \\
\text { ENG_netti.pdf) }\end{array}$ \\
\hline $\begin{array}{l}\text { Learning } \\
\text { environment }\end{array}$ & $\begin{array}{l}\text { Facilities motivating students to work } \\
\text { collaboratively. } \\
\text { Offer laboratories, technologies, modern } \\
\text { classrooms, virtual learning, simulating rooms, etc. }\end{array}$ & $\begin{array}{l}\text { Planning and designing learning } \\
\text { environments collectively. }\end{array}$ \\
\hline Internationalization & $\begin{array}{l}\text { Internationalization as a goal. } \\
\text { Enhancing international cooperation. } \\
\text { Degree programs in English. } \\
\text { Offering of International education-training } \\
\text { programs. }\end{array}$ & Degree programs individually. \\
\hline $\begin{array}{l}\text { Sustainable } \\
\text { development }\end{array}$ & $\begin{array}{l}\text { Degree program in sustainable development } \\
\text { (SusDev). } \\
\text { Researches into SusDev education. }\end{array}$ & No projects. \\
\hline Entrepreneurship & $\begin{array}{l}\text { Pre-incubator activities on campuses since } 2004 . \\
\text { School of Entrepreneurship and Business } \\
\text { offers modules to all students. } \\
\text { Participation in national projects. }\end{array}$ & $\begin{array}{l}\text { Pre-incubator support; modules } \\
\text { from the School of Entrepreneurship } \\
\text { and Business. }\end{array}$ \\
\hline $\begin{array}{l}\text { Student counselling } \\
\text { and guidance }\end{array}$ & $\begin{array}{l}\text { Offers guidance and counseling since the } \\
\text { beginning of the learning process in face-to-face } \\
\text { courses and online courses. } \\
\text { Peer-to-peer mentoring. }\end{array}$ & $\begin{array}{l}\text { Student guidance from the personal } \\
\text { study path (PSP), face-to-face and } \\
\text { online module about guidance. }\end{array}$ \\
\hline $\begin{array}{l}\text { Teaching } \\
\text { competences and } \\
\text { methods }\end{array}$ & $\begin{array}{l}\text { Coaching programs for teachers developing their } \\
\text { competencies and teaching. } \\
\text { Made cooperation with partners to develop its } \\
\text { pedagogy }\end{array}$ & $\begin{array}{l}\text { Coaching program } 2010 \text { to 2012; } \\
\text { HAMK } 100 \text { program began in 2018; } \\
\text { KOPE, EEP and eAMK project and } \\
\text { Aalto University partnership. }\end{array}$ \\
\hline
\end{tabular}

\section{Source: authors.}


Figure 5 summarizes HAMK's pedagogical aspects based on the ten thematic approaches. It also shows where the guidelines have come from and the projects related to them. The colors characterize the development level, in which green represents a consolidated status, yellow represents a highlighted point at HAMK connected with strong projects, and red represents an approach which is less emphasized. Therefore, a student-centered, competence-based curriculum, the learning environment and counseling and guidance are consolidated approaches at HAMK. Digitalization, a working life orientation, internationalization and entrepreneurship are highlighted points and connected with strong projects. Sustainable development is an approach which few commented on the interviews and is consequently less emphasized, even though HAMK has set an important target with MoEC and committed to it in the HESI (SUSTAINABLE DEVELOPMENT KNOWLEDGE PLATFORM, 2018; FRIMAN et al., 2018) project. 
Figure 5: HAMK's State of development.

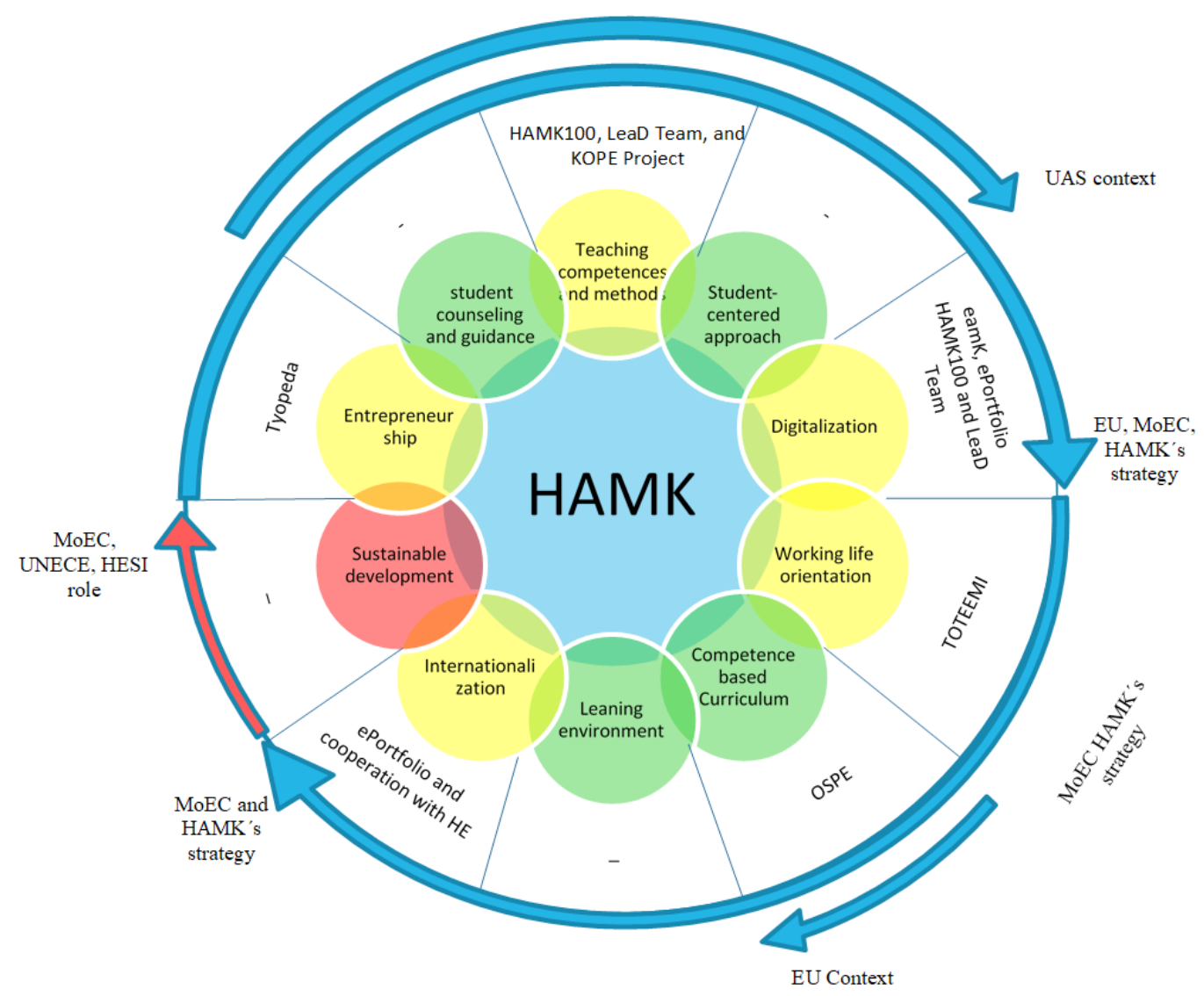

Green: Advanced.

Yellow: Developing: Highlights pedagogical points connected with strong projects.

Red: Emerging.

Figure 5 shows that HAMK has created an atmosphere and has set team objectives as well as motivated peer development so that teachers can collaborate and develop faster. There are a lot of research projects and activities going on at the university. In that context, during the interview, we came up with a further question: "How can the research and projects' achievements be used or shared so that all the teachers and staff could benefit from them?" We believe that this could be helpful to enhance pedagogical development. Another question was "What kind of impact could pedagogical development achieve on the student, teacher, institutional and regional levels?" 


\section{CONCLUSION}

It is a challenge to develop pedagogy in HEls in a world that is in a state of constant change. Nowadays, Finnish HEls receive strong support came from the EU and MoEC which have been guiding the HEls and have given them the opportunity to develop nationally and internationally to enhance their pedagogical development. Rectors, directors and deans have played an important role, since it is partly a top-down steering process to develop HEls, as mentioned by Friman, et al. (2018). It is highly important to set clear targets (NURMI \& MAHLAMÄKI-KULTANEN, 2015), prioritize them, and to ensure the connections between the processes and projects. Furthermore, teachers and other staff members need support to succeed. The institution should find ways to provide training, guarantee teacher wellbeing and manage time, as Kunnari et al. (2018) and Postareff et al. (2007) have mentioned. The pedagogical development should be continuous in HEls to achieve positive impact for the teachers and, consequently, the learners (POSTAREFF et al., 2007). As mentioned in the interviews, it is important to face the challenge of engaging in cooperation with enterprises, so that the understanding of future needs can be enhanced and development can be oriented towards it.

This research shows HAMK's stage of pedagogical development through the thematic approach. The results show that HAMK, nowadays, has a student-centered, competence-based curriculum, in addition to a positive learning environment and counseling and guidance as strong points. Furthermore, HAMK has strong national project connected to developing digitalization, a working life orientation, internationalization, entrepreneurship and teachers' competencies and methods. The research has pointed out sustainable development as a weak point. Indeed, learning about sustainability in the disciplines and degree programs was not yet indicated or connected to society. This is a challenge which HAMK needs to face and has to find ways to put into practice.

However, HAMK does not have a document that defines the pedagogical goals at HAMK, although the university has defined its targets in the HAMK Strategy 2030 with some important points and has used strategy meetings to emphasize and align guidelines. A dialogue and balance between many of the development areas are necessary. One important issue that HAMK's managers should take into account is how to create synergy and connections between divisions and development areas in order to encourage a dialogue and achieve a balance of the thematic approach. HAMK has run a coaching program, the HAMK 100 program, and the LeaD Team project to support teachers' pedagogical development, motivate peer development and set team objectives to enhance development. Individual plans are set between teachers and heads so that teachers can plan their development according to individual needs and interests. Student feedback is always considered so the UAS can understand what should be improved and focus on the best practices. 
Pedagogical development should be thought of as a continuing process, and as an issue which must be always updated. Setting pedagogical and managerial targets is a challenging and fundamental issue. The synergy of an organization supports the valorization and implementation of pedagogic development. In-house actions prioritize needs awareness, strategy, negotiations, and co-operation. The main points for the successful pedagogical development are (1) prioritization, (2) systematic progress and quality assurance and (3) co-operation between the pedagogic actors.

\section{ACKNOWLEDGEMENTS}

We would like to express our sincere gratitude to Leena Nikander and Jaana Kullaslahti who have contributed by providing important information and contributing knowledge gained through their personal experience to writing this article. Additionally, we would like to thank other HAMK experts who contributed positively to this research. We would also like to thank Vice Rector Katri Ojasalo from Laurea UAS and Vice Rector Heidi Ahokallio-Leppälä from Häme UAS for their valuable comments.

\section{REFERENCES}

ANON. 2003/2015. Act on polytechnics 15.5.2003/352, repealed from 1.12015 onwards.

AGREEMENT BETWEEN THE MINISTRY OF EDUCATION AND CULTURE AND HÄME UNIVERSITY OF APPLIED SCIENCES Ltd For 2017-2020.

AUDIT OF HÄME UNIVERSITY OF APPLIED SCIENCES 2016. Available in: https://www.hamk.fi/wpcontent/uploads/2018/08/KARVI_2816.pdf. Accessed on: November 2018.

BARNETT, R. Imagining the University. Abingdon: Routledge, 2013.

BIGGS, J.B. \& TANG, C. Teaching for Quality Learning at University. (4th Ed.). Maidenhead: McGraw Hill Education \& Open University Press, 2011.

BOLOGNA DECLARATION IN 1999. Available in: https://www.eurashe.eu/library/modernising-phe/ Bologna_1999_Bologna-Declaration.pdf Accessed on: February 2019.

CAMPBELL, C., KARJALAINEN, A., LORBER, L., MILTA, M., TANSKANEN, M., MUSTONEN, M. \& AUREN, H. 2016. Audit of Häme University of Applied Sciences 2016. Finnish Education Evaluation Center. Publications 28:2016. Available in: http://karvi.fi/en/publication/audit-of-hame-university-of-applied. sciences-2016. Accessed on 10 September 2018. 
CARVALHO, C.C.; FRIMAN, M.; MAHLAMÄKI-KULTANEN, S. (2018) Overview of the pedagogical approaches used in Finnish higher education. PEDAFORUM CONFERENCE. 15th to 16th of August, Turku, Finland.

DEVELOPING A COMPETENCY-BASED CURRICULUM FOR FINNISH HIGHER EDUCATION". Available in: http://ospe.utu.fi/tiedotteet/Ospe_kriteeristo_102x21cm_8s_2014_ENG_netti.pdf. Accessed on 10 September 2018.

eAMK. Available in: http://www.eamk.fi/en/frontpage/. Accessed on October 2018.

EEP - Empowerment ePortfolio Process. Available in: https://eepeu.wordpress.com/. Accessed on July 2018.

EGGINS, H. Globalization and reform: necessary conjunctions in higher education. In H. Eggins (ed.) Globalization and reform in Higher Education. Buckingham: SRHE and Open University Press, 1-8, 2003.

FRIMAN, M., SALMINEN, J. AND SALMINEN, R. HAMK-yhteistyö strategian uudistajana. In: Tekojen kautta - Hämeen ammattikorkeakoulun yhteisöllinen startegian uudistusprosessi, L. Mustonen (Ed.). - HAMK Publications 4: 31-44, 2014.

FRIMAN, M., SCHREIBER, D., SYRJÄNEN, R., KOKKONEN, E., MUTANEN, A., SALMINEN, J. Steering sustainable development in higher education - Outcomes from Brazil and Finland. Journal of Cleaner Production 186, 364-372, 2018.

GIBBONS, M., LIMOGES, NOWOTNY, H., SCHARTZMAN, S, SCOTT, P., TROW, M. The new production of knowledge. Sage Publications, London, 1994.

HAMK - Häme university of applied sciences. Available in: https://www.hamk.fi/. Accessed on July 2018.

HAMK 100 programme. Available in: https://blog.hamk.fi/hamk100/ Accessed on July 2018.

HAMK 2030 - Through Actions. Available in: https://www.hamk.fi/strategy/?lang=en\&cn-reloaded=1. Accessed on June 2019. 
JONGBLOED, B., \& VOSSENSTEIN, H. In conclusion: doing more with less. New ways of providing and financing Higher Education in the Post-massification era. In B. Jongbloed, \& H. Vossenstein (eds.) Access and Expansion Post Massification. Opportunities and barriers to further growth in Higher Education Participation. New York: Routledge, 238-253, 2016.

KETTUNEN, J. Innovation Pedagogy for Universities of Applied Sciences. Creative Education, Sciences Research, vol. 2, no. 1, 56-62, 2011.

KOPE Project - Korkeakoulupedagogiikkaa. Available in: https://blogi.oamk.fi/2017/11/30/2903/ Accessed on June 2018.

KUNNARI I.; ILOMÄKI, L \& TOOM, A. Successful Teacher Teams in Change: The Role of Collective Efficacy and Resilience. International Journal of Teaching and Learning in Higher Education, v30, n1, 111-126, 2018.

KUNNARI, I. Teachers changing higher education - from coping with change to embracing change. Doctor These. Faculty of Educational Sciences of the University of Helsinki, Helsinki, Finland, 2018a. . Eportfolios in project work recruitment. HAMK Unlimited Professional 25.6.2018. Available in: https://unlimited.hamk.fi/ammatillinen-osaaminen-ja-opetus/eportfolios-in-projectwork-recruitment. Accessed on July 2018b.

How can ePortfolios work in a big university hospital? HAMK Unlimited Professional

8.6.2018. Available in: https://unlimited.hamk.fi/ammatillinen-osaaminen-ja-opetus/eportfolios-inuniversity-hospital Accessed on July 2018c.

MALINEN, H., PUOLANNE, E., SORVISTO, M., SUOMALAINEN, M., TAKALA, M., MUSTONEN, ,K. \& ÖSTMAN, K. 2011. Hämeen ammattikorkeakoulun laadunvarmistusjärjestelmän auditointi. Available in: https://karvi.fi/app/uploads/2014/09/KKA_0611.pdf. Accessed on August 2018.

MoEC - Ministry of Education and Culture - MINEDU. Available in: http://minedu.fi/en/frontpage. Accessed on May 2018.

Ministry of Education and Culture, Finland. (2014). Universities of Applied Sciences Act 932/2014. Translation from Finnish. Available in: http://www.finlex.fi/en/laki/kaannokset/2014/en20140932.pdf . Accessed on January 2018. 
NURMI, R. \& MAHLAMÄKI-KULTANEN, S. Ammattikorkeakoulujen pedagogiset strategiat. (Pedagogical Strategies of the Universities of Applied Sciences). Ammattikasvatuksen aikakauskirja 17 (3), pages 24-40, 2015.

OSMAN \& HORNSKY. Transforming teaching and learning in higher education: towards a socially just pedagogy in a global context. Towards a Socially Just Pedagogy in a Global Context. Palgrave Macmillan, 2017.

PARPALA, A., \& LINDBLOM-YLÄNNE, S. UNIVERSITY Teachers 'conceptions Of Good Teaching In The Units Of High-quality Education. Studies in Educational Evaluation, 33(3-4), 355-370, 2007.

Participation of Finnish universities of applied sciences in the European higher education area. Final Report of the Project.

PATTON, M. Q. Qualitative Research \& Evaluation Methods. 3rd edition. Thousand Oaks; Sage Publication, 2002.

PIAGET, J. The psychology of intelligence. London: Routledge, 2001.

PIRES, A. Between Challenges and Trends of Lifelong learning: Higher Education and the Recognition of Prior Experiential Learning. In B. Jongbloed, \& H. Vossenstein. Access and Expansion Post Massification. Opportunities and barriers to further growth in Higher Education Participation. London: Routledge, 212-237, 2016.

PIRES, A., RODRIGUES, M., \& PESSOA, A. Transforming pedagogy in Higher Education. HAMK Unlimited Journal 26.1.2018. Available in: https://unlimited.hamk.fi/ammatillinen-osaaminen-ja-opetus/ transforming-pedagogy-in-higher-education. Accessed on July, 2018.

POSTAREFF L., LINDBLOM-YLANNE S., NEVGI A. The effect of pedagogical training on teaching in higher education. Teaching and Teacher Education, 23 (5) , pp. 557-571, 2007.

RAMAN, S. The Bologna Process and Finnish Universities of Applied Sciences, 2007.

_. Emerging Trends in Higher Education Pedagogy. Edited. WOU Press, 2016. ISBN 978983-3910-03-8.

RYAN, A., \& TILBURY, D. (2013). Flexible Pedagogies: new pedagogical ideas. York: The Higher Education Academy. 


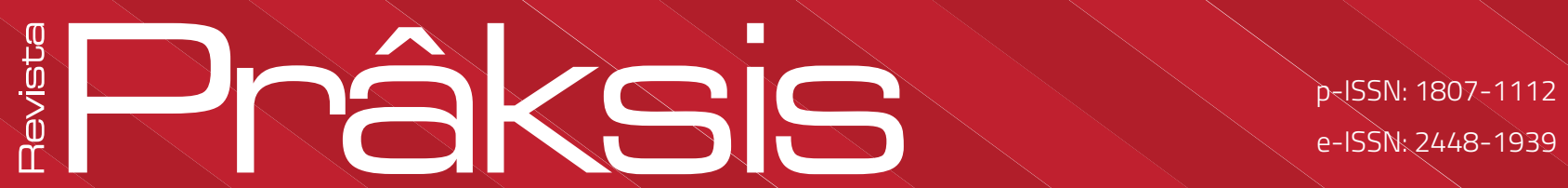

SALMINEN, H. Suomalainen ammattikorkeakoulu-uudistus opetushallinnon prosessina. Koulutus- ja tiedepolitiikan osaston julkaisusarja. Helsinki: Opetusministeriö, 2001.

SPORN, B. Trends relating to higher education reform in Europe: an overview. In H. Eggins (ed.)

Globalization and reform in Higher Education. Buckingham: SRHE and Open University Press, 117130, 2003.

Standards and Guidelines for Quality Assurance in the European Higher Education Area (ESG), 2015. Brussels, Belgium.

Sustainable Development Knowledge Platform. Available in: <https://sustainabledevelopment.un.org/ topics/education>. Accessed on July 2018.

TAYLOR, W. (2003). Steering change in tertiary education. In H. Eggins (ed.) Globalization and reform in Higher Education. Buckingham: SRHE and Open University Press, 11-31.

TOTEEMI. Available in: http://www.amktoteemi.fi/en. Accessed on July 2018.

VIEIRA, F., SILVA, J., \& ALMEIDA, J. Transformar a pedagogia na universidade: possibilidades e constrangimentos. In F. Vieira (ed.) Transformar a Pedagogia na Universidade - narrativas da prática. Santo Tirso: De Facto, 17-38, 2009.

VYGOTSKY, L. S. Mind in society: The development of higher psychological processes. In M. Cole, V. John-Steiner, S. Scribner and E. Souberman (Eds.). Cambridge, MA: Harvard University Press, 1978. 